\title{
Effect of Potassium Lactate and a Potassium Lactate-Sodium Diacetate Blend on Listeria monocytogenes Growth in Modified Atmosphere Packaged Sliced Ham
}

\author{
L. A. MELLEFONT* AND T. ROSS \\ Australian Food Safety Centre of Excellence, Tasmanian Institute of Agricultural Research, School of Agricultural Science, \\ University of Tasmania, Private Bag 54, Hobart 7001, Tasmania, Australia
}

MS 07-051: Received 30 January 2007/Accepted 9 May 2007

\begin{abstract}
Two commercially available organic acid salts, potassium lactate (PURASAL HiPure P) and a potassium lactate-sodium diacetate blend (PURASAL Opti.Form PD 4), were assessed as potential inhibitors of Listeria monocytogenes growth in modified atmosphere packaged (MAP) sliced ham in challenge studies. The influence of the initial inoculation level of $L$. monocytogenes $\left(10^{1}\right.$ or $\left.10^{3} \mathrm{CFU} \mathrm{g}^{-1}\right)$ and storage temperature $\left(4\right.$ or $\left.8^{\circ} \mathrm{C}\right)$ was also examined. The addition of either organic acid salt to MAP sliced ham strongly inhibited the growth of $L$. monocytogenes during the normal shelf life of the product under ideal refrigeration conditions $\left(4^{\circ} \mathrm{C}\right)$ and even under abusive temperature conditions (i.e., $8^{\circ} \mathrm{C}$ ). During the challenge studies and in the absence of either organic acid salt, $L$. monocytogenes numbers increased by 1,000 -fold after 20 days at $8^{\circ} \mathrm{C}$ and 10 -fold after 42 days at $4^{\circ} \mathrm{C}$. Both organic acid salt treatments were found to be listeriostatic rather than listericidal. The addition of either organic acid salt to the MAP ham also reduced the growth of indigenous microflora, i.e., aerobic microflora and lactic acid bacteria. The influence of these compounds on the risk of listeriosis in relation to product shelf life is discussed.
\end{abstract}

Unlike most foodborne pathogens, Listeria monocytogenes can grow, albeit slowly, at refrigeration temperatures, in the presence of $>5 \%$ salt, and in the absence of oxygen (37). Processed meats, including ham and pâté, are often packaged under vacuum or modified atmospheres and stored under refrigeration to extend their shelf life, typically being 6 to 8 weeks or more. Although initial contamination with $L$. monocytogenes, when present, is usually low, i.e., $<10 \mathrm{CFU} \mathrm{\textrm {g } ^ { - 1 }}(15,28)$, its potential for growth in readyto-eat meats that are eaten without further cooking prior to consumption is, prima facie, considerable. Moreover, it is well documented that $L$. monocytogenes can grow in many such products during refrigerated storage, and such foods have caused, or been strongly implicated in, outbreaks of foodborne listeriosis that have resulted in fatalities $(6-8,23$, 25).

$L$. monocytogenes present on raw ingredients can be killed reliably by the heat treatments routinely applied during smallgoods processing. During slicing and packaging after processing, however, recontamination can occur (16, $18,24,30,39$ ). During the past decade, the food industry has implemented hygiene practices and technologies that have greatly reduced the prevalence of $L$. monocytogenes on ready-to-eat foods $(20,28)$. Nevertheless, the ecology of the organism, particularly its ability to colonize food processing plants (38), still results in $L$. monocytogenes being detected, typically, in $\sim 1$ to $5 \%$, or more, of processed meat products $(1,5,15,20,28,41)$.

One approach to minimize the risk of listeriosis is to

* Author for correspondence. Tel: $+61(0) 362$ 266278. Fax: $+61(0) 3$ 62 267450; E-mail: lyndal.mellefont@utas.edu.au. modify or treat long shelf life refrigerated products in such a way that the growth of $L$. monocytogenes is prevented, at least within the normal shelf life of the product. Organic acids and their salts, applied singly and in combination, have been shown by many studies to prevent or greatly retard the growth of $L$. monocytogenes in processed meats under both recommended temperatures of storage (at or below $4^{\circ} \mathrm{C}$ ) and mild temperature abuse (e.g., up to $10^{\circ} \mathrm{C}$ ). Generally, studies have focused on the activity of the sodium salts $(2-4,9,14,17,18,21,22,27,29,31,34,40)$, but several also consider potassium lactate or potassium lactate in combination with sodium diacetate $(19,26,32$, 33). Most studies have considered the activity of organic acid salts in sausage products (e.g., bratwurst, frankfurters, saveloys), but others have studied their effectiveness in cooked ham $(4,34)$. Mbandi and Shelef (21) considered the effectiveness in sterile uncooked comminuted beef emulsion.

There are a range of commercial products available based on the salts of organic acids that are intended to provide protection against the growth of undesirable microorganisms on foods. This project was undertaken to assess the antilisterial efficacy of two such products on an Australian smallgoods product, specifically, PURASAL HiPure $\mathrm{P}$ (potassium lactate) and PURASAL Opti.Form PD 4 (a potassium lactate-sodium diacetate blend). The influence, and possible interaction, of the presence of either antilisterial product, the initial level of $L$. monocytogenes, and the temperature of storage on the development of populations of L. monocytogenes in modified atmosphere packaged (MAP) sliced ham are investigated. The influence of indigenous microbiota is also considered. 


\section{MATERIALS AND METHODS}

Ham preparation. Hams were prepared under commercial conditions by a large Australian manufacturer. During processing, antilisterial treatments were applied to hams prior to cooking. The treatments were as follows: the addition of $3 \%$ (wt/wt finished product) of PURASAL Opti.Form PD 4 (a blend consisting of 54.5 to $57.5 \%$ potassium lactate and 3.7 to $4.3 \%$ sodium diacetate; Purac Asia Pacific Pte. Ltd., Singapore) or the addition of 3\% (wt/ wt finished product) of PURASAL HiPure P (58 to $62 \%$ potassium lactate). Both products were provided to the smallgoods producer by Fibrisol Service Australia Pty. Ltd. (Heatherton, Victoria, Australia). Finished hams were sliced by the manufacturer and packaged in $\sim 50$-g lots into commercial thermoformed ridge bottom packs, composed of polyethylene teraphthalate and polyethylene, and produced on horizontal form fill. The packages were then sealed under MAP $\left(30 \% \mathrm{CO}_{2}\right.$ and $70 \% \mathrm{~N}_{2}$ ). Control and treated samples were transported to the laboratory by commercial transport operators under refrigeration, but no temperature records were available.

Bacterial strains. Five strains of $L$. monocytogenes were used in combination for all "inoculated" samples. L. monocytogenes Scott A (type strain) and L5/22 (cold-smoked salmon isolate) were obtained from the School of Agricultural Science, University of Tasmania. Strains 20425, 20432, and 20423, all environmental isolates from a smallgoods factory, were supplied by Silliker Microtech Pty., Ltd., Melbourne, Victoria, Australia. Strains were maintained on bead suspensions in nutrient broth (Oxoid CM1, Oxoid Ltd., Hampshire, UK) with 15\% glycerol and stored at $-70^{\circ} \mathrm{C}$.

Preparation of inocula. Before each experiment, isolates were resuscitated from cryogenic storage by plating onto brain heart infusion agar (Oxoid CM225) and incubating at $25^{\circ} \mathrm{C}$ for 48 h. A primary culture of each strain was prepared by touching a sterile loop to five colonies and inoculating $10 \mathrm{ml}$ of prewarmed $\left(25^{\circ} \mathrm{C}\right.$ ) tryptone soya broth (Oxoid CM129) containing $0.6 \%$ yeast extract (TSBYE; Oxoid L21). The primary culture for each strain was incubated without shaking at $37^{\circ} \mathrm{C}$ for $24 \mathrm{~h}$. The primary cultures were then serially diluted in $0.1 \%$ peptone water (PW; Oxoid Bacteriological Peptone $\mathrm{L} 37$ containing $0.85 \% \mathrm{NaCl}$ ) and added to $50 \mathrm{ml}$ of TSBYE broths in $125-\mathrm{ml}$ side-arm flasks to achieve a level of approximately $10^{6} \mathrm{CFU} \mathrm{ml}^{-1}$. The cultures were then incubated with shaking ( 80 oscillations $\mathrm{min}^{-1}$ ) in a water bath (Ratek Instruments Pty. Ltd., Victoria, Australia) at $10^{\circ} \mathrm{C}$. Growth was monitored turbidimetrically $(540 \mathrm{~nm})$ until percent transmittance had decreased to $\sim 20 \%$. These steps were undertaken to generate exponentially growing inocula of $\sim 10^{8} \mathrm{CFU}$ $\mathrm{ml}^{-1}$ and acclimated to the chill temperatures considered representative of a smallgoods processing facility.

One-milliliter aliquots of the $10^{\circ} \mathrm{C}$ broth cultures of each of the five strains were added to a sterile $30-\mathrm{ml}$ bottle and vortexed for $1 \mathrm{~min}$. This "cocktail" suspension was then diluted in PW, prechilled to $10^{\circ} \mathrm{C}$, to achieve levels of inocula such that final levels in inoculated samples were $\sim 10^{1}$ or $\sim 10^{3} \mathrm{~L}$. monocytogenes CFU $\mathrm{g}^{-1}$ ham. The amount of $L$. monocytogenes in the cocktail suspension was determined by viable count.

Inoculation of ham. Upon receipt at the University of Tasmania laboratories, control (no treatment) and treated samples were stored at $2^{\circ} \mathrm{C}$ for 2 days prior to inoculation with the $L$. monocytogenes cocktail and commencement of the challenge trial.

Low- and high-density inocula, prepared as described above, were aseptically injected onto the MAP sliced ham products $(\sim 50$ $\mathrm{g}$ per package) with a hypodermic syringe to penetrate the pack- aging. Uninoculated control samples were prepared by adding 0.1 $\mathrm{ml}$ of sterile PW. To minimize the potential for cross-contamination, these control samples were prepared prior to the samples requiring inoculation with the $L$. monocytogenes.

To preserve the integrity of the gas mixture, a self-adhesive rubber septum was applied to each sample package, and the syringe was inserted into the pack through the septum. An inoculum volume of $0.1 \mathrm{ml}$ was added to a corner of the base of the package that did not contain any ham. The package was then inverted and gently shaken (by hand) so that the slices of ham moved across the inner surfaces of the container and each other. This was done to maximize the likelihood of even distribution of cells of $L$. monocytogenes or sterile diluent throughout the sample. Immediately after inoculation (or addition of sterile PW), the septum was covered with self-adhesive tape. Inoculated samples were appropriately labeled and incubated at either 4 or $8^{\circ} \mathrm{C}$ in walk-in cool-rooms. The duration of storage was $\leq 76$ and $\leq 57$ days for samples stored at 4 and $8^{\circ} \mathrm{C}$, respectively.

Sampling. At appropriate time intervals, three samples from each treatment or control were assessed for levels of $L$. monocytogenes, concentrations of lactic acid bacteria, and aerobic plate count (APC). The entire sample from each package was aseptically removed and diluted 1:1 in PW and stomached for $2 \mathrm{~min}$. Further 10-fold dilutions in PW were prepared as required, and 100 - or $250-\mu l$ aliquots were surface plated with a spiral plater (Autoplate 4000, Spiral Biotech Inc., Bethesda, Md.) onto agar plates as follows. PALCAM plates (Oxoid CM877, and SR150 antibiotic supplement) for $L$. monocytogenes were incubated aerobically at $37^{\circ} \mathrm{C}$ for $48 \mathrm{~h}$. The deMan Rogosa Sharpe agar (Oxoid CM361) plates for lactic acid bacteria were incubated aerobically at $25^{\circ} \mathrm{C}$ for $72 \mathrm{~h}$. Plate count agar plates (Oxoid CM463 APHA Standard Plate Count Agar) for APCs were incubated at $20^{\circ} \mathrm{C}$ for $72 \mathrm{~h}$. Colonies were counted manually, and $\log$ (viable cell count) of the triplicate samples was averaged ( \pm standard deviation) and plotted against time. The maximum sample volume plated was $250 \mu \mathrm{l}$ of the 1:1 dilution on quadruplicate plates. This permitted a maximum test sensitivity of $2 \mathrm{CFU} \mathrm{g^{-1 }}$.

Water activity (Aqualab CX2, Decagon Devices, Pullman, Wash.) and direct measurement of the $\mathrm{pH}(\mathrm{pH}$ meter 250A, Orion Research Inc., Boston, Mass.) of the ham were also determined from triplicate samples taken near the commencement of incubation and periodically throughout the trial.

\section{RESULTS}

Because of the time taken to transport the hams from the commercial processor to the laboratory and to prepare the inoculum, the time between preparation of the hams and commencement of the challenge trial was 11 days. Changes in the microbial ecology and physicochemical attributes of the product were expected to commence from the time of packaging. Thus, all incubation times reported below relate to the time since commercial preparation, not the time of commencement of the challenge study. The manufacturer's shelf life recommendation for the untreated commercial product under the recommended refrigerated storage conditions was $\sim 42$ days.

The challenge trial was conducted once for each combination of control or antilisterial product, incubation temperature, and level of $L$. monocytogenes, with triplicate samples analyzed at each sampling time. 
TABLE 1. $p H$ changes over time in control and PURASAL-treated ham samples during storage at either 4 or $8^{\circ} \mathrm{C}(\mathrm{n}=3)^{a}$

\begin{tabular}{|c|c|c|c|c|c|c|c|c|}
\hline \multirow{2}{*}{$\begin{array}{l}\text { Temp } \\
\left({ }^{\circ} \mathrm{C}\right)\end{array}$} & \multirow[b]{2}{*}{ Ham treatment } & \multicolumn{7}{|c|}{ Sample time (days): } \\
\hline & & 21 & 38 & 46 & 60 & 74 & 88 & \\
\hline $4 C$ & $\begin{array}{l}\text { Control (untreated, no } \\
\text { L. monocytogenes) }\end{array}$ & $6.44 \pm 0.03$ & $6.40 \pm 0.13$ & NT & NT & $6.15 \pm 0.07$ & $6.48 \pm 0.06$ & \\
\hline & $\begin{array}{l}\text { Untreated, } \sim 10^{1} \mathrm{CFU} \mathrm{g}^{-1} \\
\text { L. monocytogenes }\end{array}$ & $6.46 \pm 0.02$ & $6.44 \pm 0.04$ & $6.42 \pm 0$ & $6.19 \pm 0.04$ & $6.07 \pm 0.03$ & $6.43 \pm 0.10$ & \\
\hline & $\begin{array}{l}\text { Untreated, } \sim 10^{3} \mathrm{CFU} \mathrm{g}^{-1} \\
\text { L. monocytogenes }\end{array}$ & $6.40 \pm 0.12$ & $6.50 \pm 0.03$ & $6.44 \pm 0.05$ & $6.20 \pm 0.05$ & $6.10 \pm 0.003$ & $6.41 \pm 0.11$ & \\
\hline & $\begin{array}{l}\text { Hi Pure } \mathrm{P}, \sim 10^{1} \mathrm{CFU}^{-1} \\
\text { L. monocytogenes }\end{array}$ & $6.40 \pm 0.01$ & $6.44 \pm 0.02$ & $6.48 \pm 0.06$ & $6.12 \pm 0.05$ & $6.19 \pm 0.03$ & $6.20 \pm 0.04$ & \\
\hline & 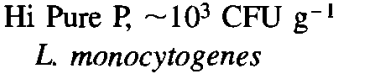 & $6.48 \pm 0.05$ & $6.44 \pm 0.03$ & $6.47 \pm 0.08$ & $6.16 \pm 0.03$ & $6.23 \pm 0.04$ & $6.21 \pm 0.03$ & \\
\hline & $\begin{array}{l}\text { Opti.Form PD } 4,10^{1} \mathrm{CFU} \\
\mathrm{g}^{-1} \text { L. monocytogenes }\end{array}$ & $6.47 \pm 0.04$ & $6.44 \pm 0.03$ & $6.45 \pm 0.06$ & $6.08 \pm 0.10$ & $6.24 \pm 0.04$ & $6.21 \pm 0.03$ & \\
\hline & $\begin{array}{l}\text { Opti.Form PD } 4, \sim 10^{3} \mathrm{CFU} \\
\mathrm{g}^{-1} \text { L. monocytogenes }\end{array}$ & $6.44 \pm 0.05$ & $6.45 \pm 0.05$ & $6.43 \pm 0.04$ & $6.19 \pm 0.08$ & $6.23 \pm 0.04$ & $6.22 \pm 0.01$ & \\
\hline \multirow{2}{*}{$\begin{array}{l}\text { Temp } \\
\left({ }^{\circ} \mathrm{C}\right)\end{array}$} & & \multicolumn{7}{|c|}{ Sample time (days): } \\
\hline & Ham treatment & 13 & 20 & 24 & 31 & 41 & 61 & 68 \\
\hline $8 C$ & $\begin{array}{l}\text { Control (untreated, no } \\
\text { L. monocytogenes) }\end{array}$ & $6.23 \pm 0.05$ & $6.14 \pm 0.02$ & $6.52 \pm 0.06$ & $6.20 \pm 0.01$ & NT & $5.85 \pm 0.11$ & $5.59 \pm 0.24$ \\
\hline & $\begin{array}{l}\text { Untreated, } \sim 10^{1} \mathrm{CFU} \mathrm{g}^{-1} \\
\text { L. monocytogenes }\end{array}$ & $6.21 \pm 0.04$ & $6.16 \pm 0.04$ & $6.45 \pm 0.06$ & $6.17 \pm 0.04$ & $6.37 \pm 0.20$ & $5.95 \pm 0.10$ & $5.71 \pm 0.14$ \\
\hline & $\begin{array}{l}\text { Untreated, } \sim 10^{3} \mathrm{CFU} \mathrm{g}^{-1} \\
\text { L. monocytogenes }\end{array}$ & $6.19 \pm 0.02$ & $6.18 \pm 0.02$ & $6.45 \pm 0.03$ & $6.20 \pm 0.02$ & $6.27 \pm 0.21$ & $5.84 \pm 0.12$ & $5.75 \pm 0.17$ \\
\hline & $\begin{array}{l}\text { Hi Pure } \mathrm{P}, \sim 10^{1} \mathrm{CFU} \mathrm{g}^{-1} \\
\quad \text { L. monocytognes }\end{array}$ & $6.24 \pm 0.03$ & $6.17 \pm 0.01$ & $6.45 \pm 0.04$ & $6.22 \pm 0.01$ & $6.49 \pm 0.01$ & $6.11 \pm 0.02$ & $6.22 \pm 0.03$ \\
\hline & $\begin{array}{l}\text { Hi Pure } \mathbf{P}, \sim 10^{3} \text { CFU } \mathrm{g}^{-1} \\
\text { L. monocytogenes }\end{array}$ & $6.23 \pm 0.04$ & $6.16 \pm 0.04$ & $6.46 \pm 0.03$ & $6.14 \pm 0.02$ & $6.44 \pm 0.01$ & $6.23 \pm 0.09$ & $6.17 \pm 0.03$ \\
\hline & $\begin{array}{l}\text { Opti.Form PD } 4, \sim 10^{1} \mathrm{CFU} \\
\mathrm{g}^{-1} \text { L. monocytogenes }\end{array}$ & $6.21 \pm 0.05$ & $6.18 \pm 0.03$ & $6.45 \pm 0.03$ & $6.19 \pm 0.02$ & $6.53 \pm 0.10$ & $6.15 \pm 0.07$ & $6.20 \pm 0.03$ \\
\hline & $\begin{array}{l}\text { Opti.Form PD } 4, \sim 10^{3} \mathrm{CFU} \\
\mathrm{g}^{-1} \text { L. monocytogenes }\end{array}$ & $6.25 \pm 0.06$ & $6.19 \pm 0.03$ & $6.43 \pm 0.02$ & $6.16 \pm 0.04$ & $6.46 \pm 0.06$ & $6.22 \pm 0.08$ & $6.16 \pm 0.03$ \\
\hline
\end{tabular}

${ }^{a}$ NT, not tested.

Water activity, gas mixture, and pH changes. The water activity of control and treated ham samples showed little change during storage at either 4 or $8^{\circ} \mathrm{C}$ (data not shown). Moreover, the addition of either a sterile diluent or small volume of inoculum to the hams did not affect water activity. Overall, untreated hams had a higher average water activity $(0.969 \pm 0.003 ; n=27)$ than hams treated with either the potassium lactate-sodium diacetate blend $(0.959$ $\pm 0.005 ; n=18)$ or potassium lactate $(0.959 \pm 0.002 ; n$ $=18$ ).

The $\mathrm{pH}$ values of the control (untreated) and treated ham samples over time of incubation at 4 and $8^{\circ} \mathrm{C}$ are shown in Table 1 . The pattern of response was initially similar for all ham types at $4^{\circ} \mathrm{C}$. The $\mathrm{pH}$ remained constant at $\sim 6.4$ up to 46 days postprocessing and then declined to $\sim 6.2$. Thereafter, the $\mathrm{pH}$ of treated hams remained unchanged. Untreated hams, both inoculated and uninoculated, returned to a $\mathrm{pH}$ similar to that at commencement of the trial. At $8^{\circ} \mathrm{C}, \mathrm{pH}$ changes were similar for all hams up to 31 days postprocessing, with $\mathrm{pH}$ fluctuating between $\sim 6.2$ and 6.4. This pattern continued for the duration of the trial for hams treated witf either antilisterial agent. For untreated hams, both uninoculated and inoculated with $L$. monocytogenes, the $\mathrm{pH}$ declined after 40 days to $\sim 5.6$ to 5.7 .

The gas composition of selected samples, assessed periodically throughout the trial, showed no systematic changes (data not shown).

Untreated control ham. The data for the uninoculated and inoculated untreated hams provide the baseline against which the efficacy of the two treatments can be assessed. The APC reached maximum population density by day 54 at $4^{\circ} \mathrm{C}$ and day 34 at $8^{\circ} \mathrm{C}$ for both uninoculated and untreated hams inoculated with either low or high numbers of L. monocytogenes (Figs. 1a through $1 \mathrm{c}$ and $2 \mathrm{a}$ through $2 \mathrm{c}$ ). In all cases, the APC mainly consisted of lactic acid bacteria. L. monocytogenes was not recovered from uninoculated control samples stored at either 4 or $8^{\circ} \mathrm{C}$ (Figs. 1a and 2a) with a level of detection of $<2 \mathrm{CFU} \mathrm{g}^{-1}$.

$L$. monocytogenes inoculated into untreated samples and stored at 4 or $8^{\circ} \mathrm{C}$ showed growth. At $4^{\circ} \mathrm{C}$, approximately $1 \log$ of growth was observed 42 days after inoculation for ham with either low (Fig. 1b) or high (Fig. 1c) 

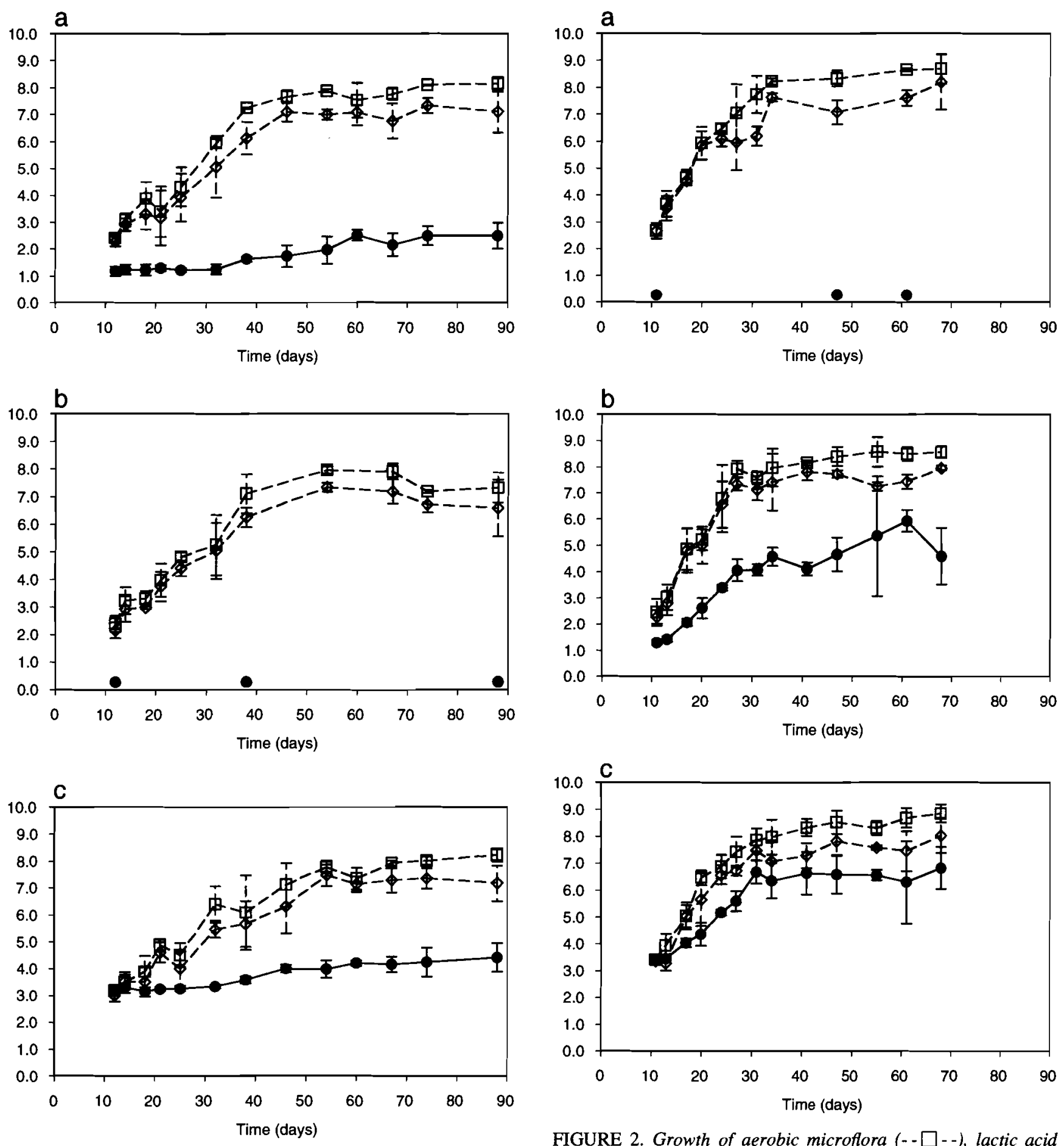

FIGURE 1. Growth of aerobic microflora (-- $\square--)$, lactic acid bacteria $(--\diamond--)$, and $\mathrm{L}$. monocytogenes $(\bullet)$ in untreated modified atmosphere packaged sliced ham stored at $4^{\circ} \mathrm{C}$ where $(a)$ uninoculated control, $(b)$ inoculated with low numbers $\left(\sim 10^{I}\right.$ $C F U g^{-1}$ ) of $\mathrm{L}$. monocytogenes, and (c) inoculated with high

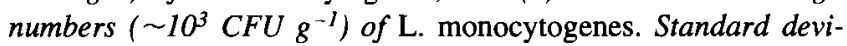
ation $(\mathrm{n}=3)$ is also plotted. For uninoculated control samples, data plotted represent a determination of $<2 C F U \mathrm{~g}^{-1}$.

added numbers of $L$. monocytogenes. More growth was observed, $\sim 3 \log$, at $8^{\circ} \mathrm{C}$ after 20 days (postinoculation) and was also independent of inoculum size (Fig. $2 b$ and $2 c$ ). Initiation of growth at $4^{\circ} \mathrm{C}$ appeared to be considerably delayed, $\sim 20$ days postinoculation, compared with that at

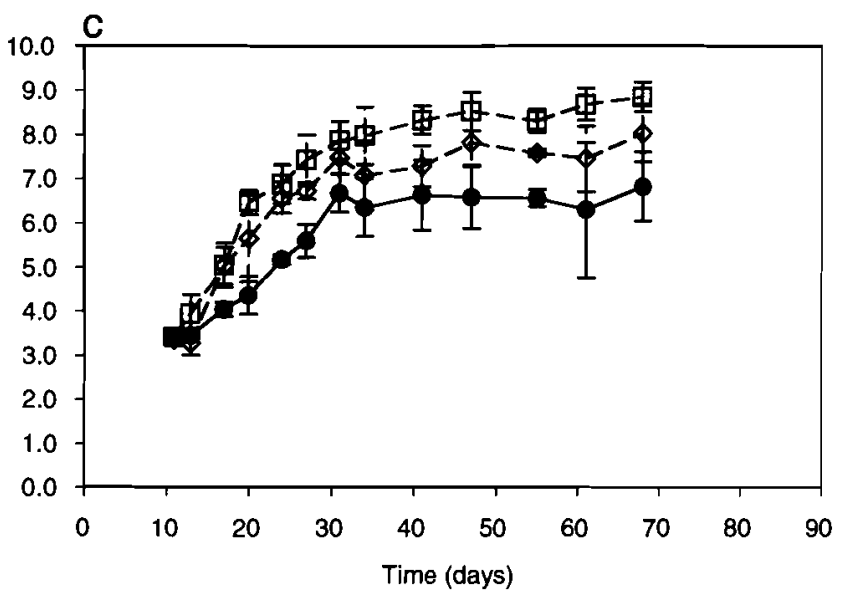

FIGURE 2. Growth of aerobic microflora (-- $\square--)$, lactic acid bacteria $(--\diamond--)$, and $\mathrm{L}$. monocytogenes $(\bigcirc)$ in untreated modified atmosphere packaged sliced ham stored at $8^{\circ} \mathrm{C}$ where (a) uninoculated control, (b) inoculated with low numbers $\left(\sim 10^{I}\right.$ $C F U g^{-1}$ ) of $\mathrm{L}$. monocytogenes, and (c) inoculated with high

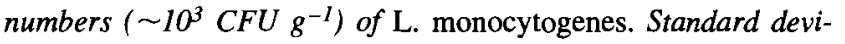
ation $(\mathrm{n}=3)$ is also plotted. For uninoculated control samples, data plotted represent a determination of $<2 \mathrm{CFU} \mathrm{g}^{-1}$.

$8^{\circ} \mathrm{C}, \sim 2$ days. In all inoculated and untreated hams, the growth of $L$. monocytogenes in the product appeared to plateau when the total number of viable aerobic bacterial cells in the samples reached $\sim 10^{8} \mathrm{CFU} \mathrm{g}^{-1}$.

Treated ham. Figures $3 a$ and $3 b$ and $4 a$ and $4 b$ show the effect of the addition of the potassium lactate-sodium 
a
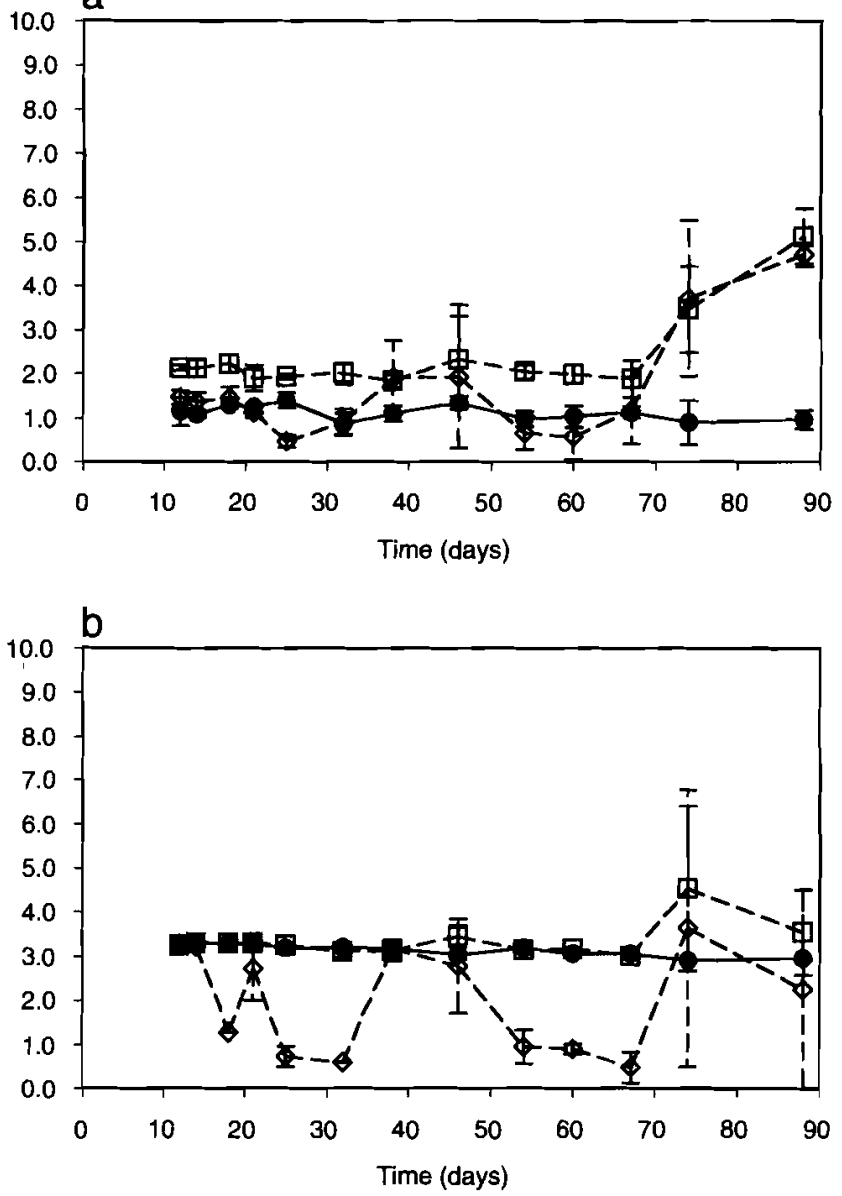

FIGURE 3. Growth of aerobic microflora (-- $\square--)$, lactic acid bacteria (-- $\diamond--)$, and $\mathrm{L}$. monocytogenes $(\bigcirc)$ at $4^{\circ} \mathrm{C}$ in modified atmosphere packaged sliced ham treated with potassium lactatesodium diacetate (PURASAL Opti.Form PD 4) and inoculated with either (a) low numbers $\left(\sim 10^{I} \mathrm{CFU} \mathrm{g}^{-1}\right)$ or $(b)$ high numbers

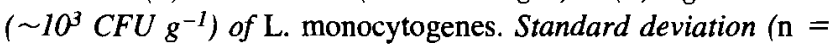
3) is also plotted.

diacetate blend, and Figures 5a and 5b and $6 \mathrm{a}$ and $6 \mathrm{~b}$ show the effect of potassium lactate on the changes in microbial populations, including added $L$. monocytogenes, in MAP sliced ham. In all cases, it was apparent that the treatments greatly reduced the extent of microbial growth when compared with untreated hams (Figs. $1 \mathrm{~b}$ and $1 \mathrm{c}$ and $2 \mathrm{~b}$ and $2 \mathrm{c}$ ).

Regardless of inoculum level, the growth of $L$. monocytogenes was prevented for 76 days (postinoculation) at $4^{\circ} \mathrm{C}$ in both potassium lactate-sodium diacetate (Fig. 3a and $3 \mathrm{~b}$ ) and potassium lactate (Fig. 5a and 5b) treated hams. Similarly, no growth of L. monocytogenes was observed on potassium lactate-treated hams after 57 days (postinoculation) at $8^{\circ} \mathrm{C}$ (Fig. 6a and $\left.6 \mathrm{~b}\right)$. A small increase $(\sim 0.5 \log$ $\mathrm{CFU} \mathrm{g}^{-1}$ ) in $L$. monocytogenes numbers was apparent in the last samples taken, i.e., 57 days postinoculation, for potassium lactate-sodium diacetate treated hams stored at $8^{\circ} \mathrm{C}$. With the Student's $t$ test, the difference between the mean of those counts and the mean of the preceding counts was found to be significant $(P<0.05)$ for the samples with low $L$. monocytogenes inoculum (Fig. $4 a$ ) and highly significant $(P<0.001)$ for the samples with high $L$. monocytogenes inoculum (Fig. $4 \mathrm{~b}$ )
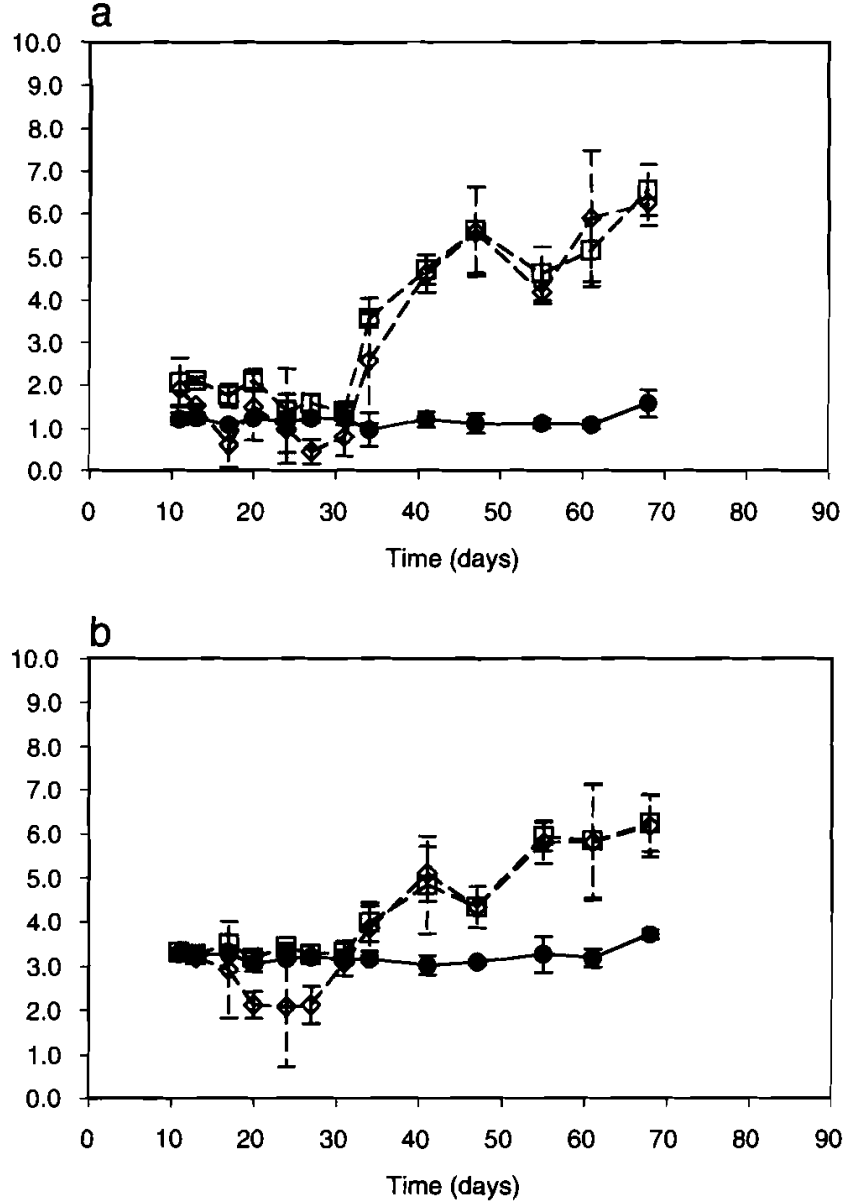

FIGURE 4. Growth of aerobic microflora (-- $\square--)$, lactic acid bacteria (- $\diamond--)$, and L. monocytogenes (O) at $8^{\circ} \mathrm{C}$ in modified atmosphere packaged sliced ham treated with potassium lactatesodium diacetate (PURASAL Opti.Form PD 4) and inoculated with either (a) low numbers $\left(\sim 10^{I} C F U g^{-1}\right)$ or $(b)$ high numbers $\left(\sim 10^{3} \mathrm{CFU} \mathrm{g}^{-1}\right)$ of $\mathrm{L}$. monocytogenes. Standard deviation $(\mathrm{n}=$ 3) is also plotted.

Both treatments at both temperatures also suppressed the growth of indigenous bacteria in terms of growth rate and time of initiation of growth compared with untreated hams. It is important to note that the APC includes the introduced $L$. monocytogenes so that, in some cases, the growth of indigenous bacteria that are present at concentrations less than $\sim 10^{3} \mathrm{CFU} \mathrm{g}^{-1}$ can be masked by the nongrowing $L$. monocytogenes population in the high inoculum treatments.

For hams treated with potassium lactate-sodium diacetate, the APC remained unchanged for 55 days (postinoculation) at $4^{\circ} \mathrm{C}$, regardless of $L$. monocytogenes inoculum level (Fig. $3 a$ and $3 b$ ). Thereafter, numbers increased slowly, in comparison to control hams, to $\sim 5$ and $4.5 \log \mathrm{CFU}$ $\mathrm{g}^{-1}$ in low and high inoculated hams, respectively. At $8^{\circ} \mathrm{C}$, APC growth was suppressed for 20 days postinoculation. Thereafter, the APC increased to $\sim 6 \log$ CFU $g^{-1}$ at a slower rate than observed in control hams inoculated with L. monocytogenes (Fig. $2 \mathrm{~b}$ and $2 \mathrm{c}$ ).

For hams treated with potassium lactate, the APC remained relatively unchanged during storage at $4^{\circ} \mathrm{C}$, i.e., for 76 days postinoculation (Fig. 5a and 5b). A small increase 
a

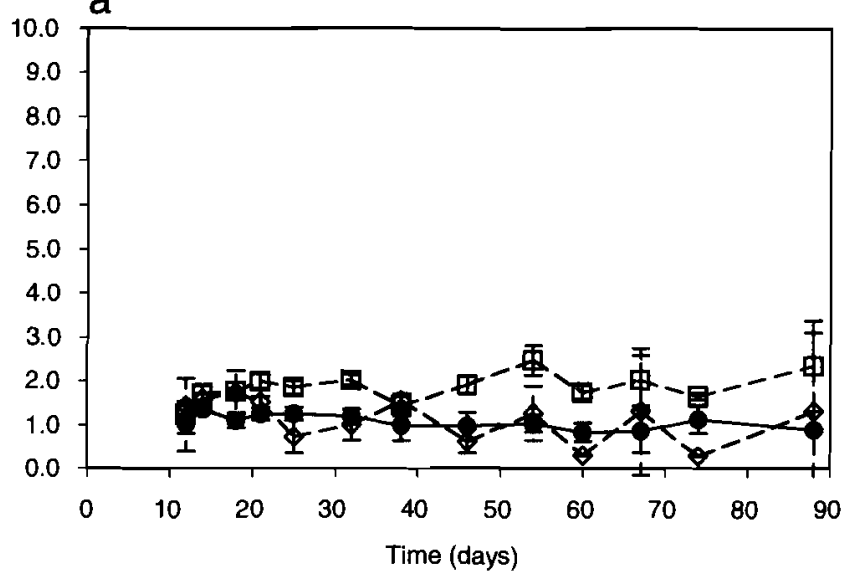

b

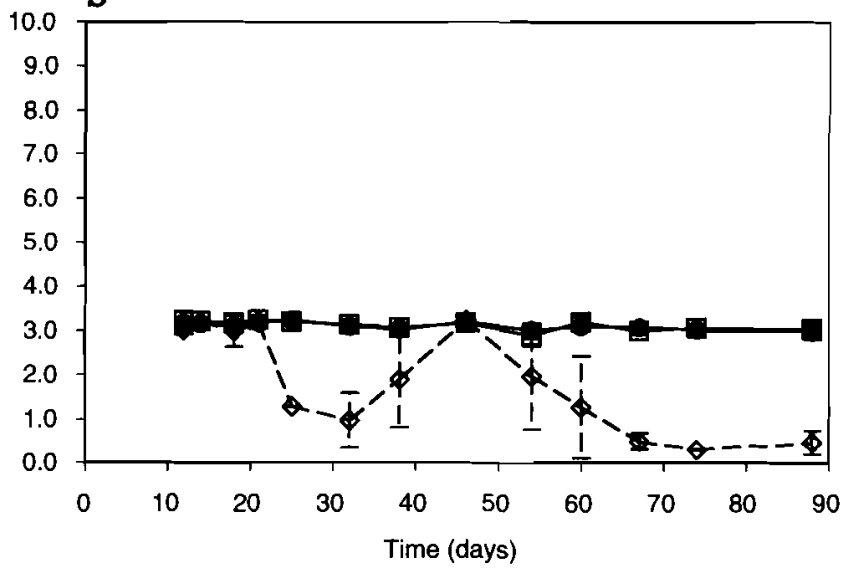

FIGURE 5. Growth of aerobic microfiora (-- $\square--)$, lactic acid bacteria (- $\diamond_{--)}$, and L. monocytogenes (O) at $4^{\circ} \mathrm{C}$ in modified atmosphere packaged sliced ham treated with potassium lactate (PURASAL HiPure P) and inoculated with either (a) low numbers $\left(\sim 10^{I} \mathrm{CFU} \mathrm{g}^{-1}\right)$ or $(b)$ high numbers $\left(\sim 10^{3} \mathrm{CFU} \mathrm{g}^{-1}\right)$ of $\mathrm{L}$. monocytogenes. Standard deviation $(\mathrm{n}=3)$ is also plotted.

in numbers may have occurred in the hams inoculated with low numbers of $L$. monocytogenes (Fig. 5a); however, the response fluctuated over the duration of storage. Note that the APC mainly consists of $L$. monocytogenes in the high inoculated hams (Fig. 5b), thus masking the response of indigenous microflora. As for potassium lactate-sodium diacetate treated hams at $8^{\circ} \mathrm{C}$ (Fig. $4 a$ and $4 b$ ), the APC is suppressed for the first 20 days of storage postinoculation. Thereafter, the APC increases. If the APC data for all treated and inoculated hams are plotted together, it is apparent that the rate of increase is slower in potassium lactate-treated hams than in those treated with the potassium lactatesodium diacetate blend (data not shown).

The response of indigenous lactic acid bacteria in the treated and inoculated hams was similar to that of the APC, particularly when growth was observed. However, when the APC remained static, it was apparent that the numbers recovered on deMan Rogosa Sharpe varied between sampling times. For example see Figure $3 b$ for hams treated with potassium lactate-sodium diacetate, inoculated with high numbers of $L$. monocytogenes, and stored at $4^{\circ} \mathrm{C}$.
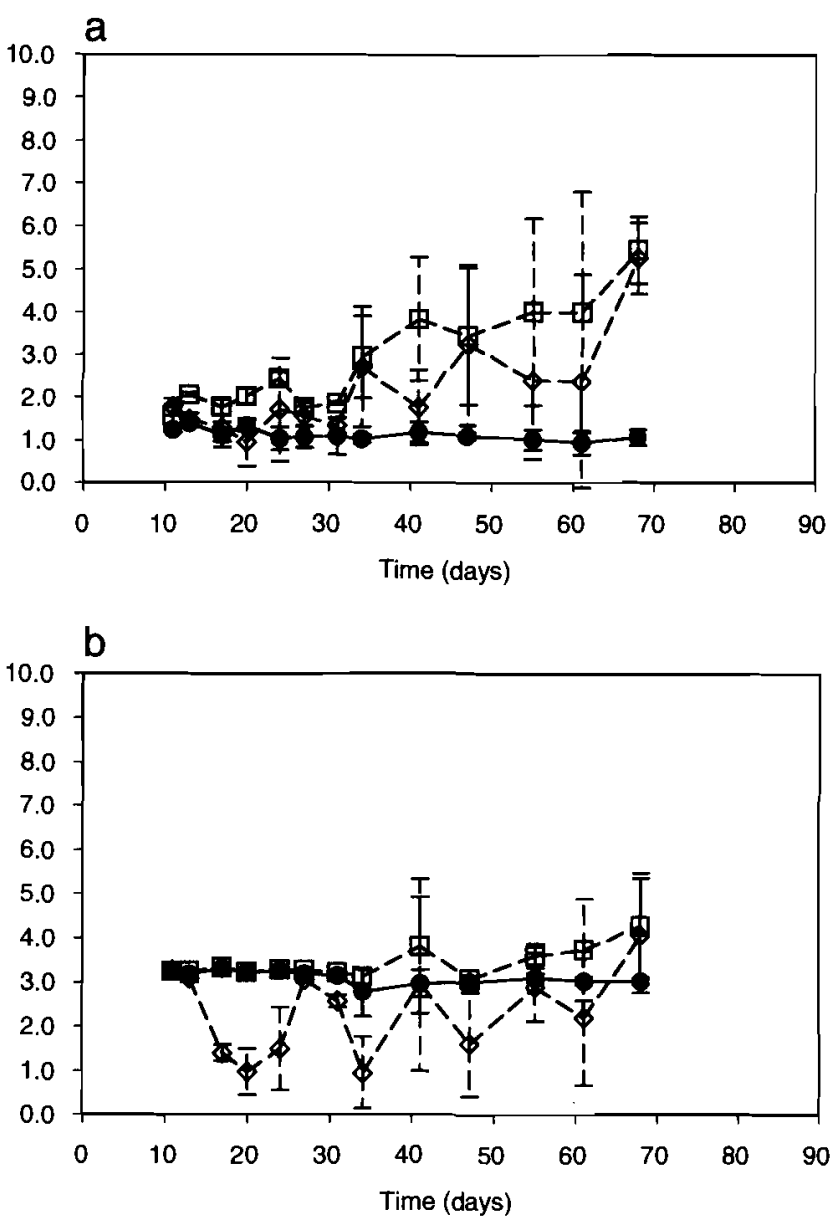

FIGURE 6. Growth of aerobic microflora (-- $\square--)$, lactic acid bacteria (- $\diamond--)$, and L. monocytogenes (O) at $8^{\circ} \mathrm{C}$ in modified atmosphere packaged sliced ham treated with potassium lactate (PURASAL HiPure P) and inoculated with either (a) low numbers $\left(\sim 10^{I} \mathrm{CFU} \mathrm{g}^{-1}\right)$ or $(\mathrm{b})$ high numbers $\left(\sim 10^{3} \mathrm{CFU} \mathrm{g}^{-1}\right)$ of $\mathrm{L}$. monocytogenes. Standard deviation $(\mathrm{n}=3)$ is also plotted.

\section{DISCUSSION}

The five $L$. monocytogenes strains used in these experiments were grown to late exponential phase and acclimated to growth at chill temperature $\left(10^{\circ} \mathrm{C}\right)$ to minimize the lag time on introduction to the ham environment. This approach appears to have been successful as, in the untreated and inoculated controls (Fig. $2 b$ and $2 c$ ) at $8^{\circ} \mathrm{C}$, there is little evidence of a lag phase before the commencement of growth. At $4^{\circ} \mathrm{C}$, however, there is a lag time of $\sim 20$ days (Fig. la and $1 \mathrm{~b}$ ). The use of a mixture of five strains of $L$. monocytogenes was intended to minimize the possibility that any observed inhibition of growth observed would be strain-specific.

To more clearly illustrate the effects of the two treatments on the potential for $L$. monocytogenes growth in MAP stored ham, Figure $7 \mathrm{a}$ and $7 \mathrm{~b}$ presents a direct comparison of the population growth of $L$. monocytogenes in untreated controls, and the respective treatments, at each of the storage temperatures and L. monocytogenes inoculum levels studied. The results support the reported effectiveness of both potassium lactate and combined potassium lactate and sodium diacetate under both recommended storage 

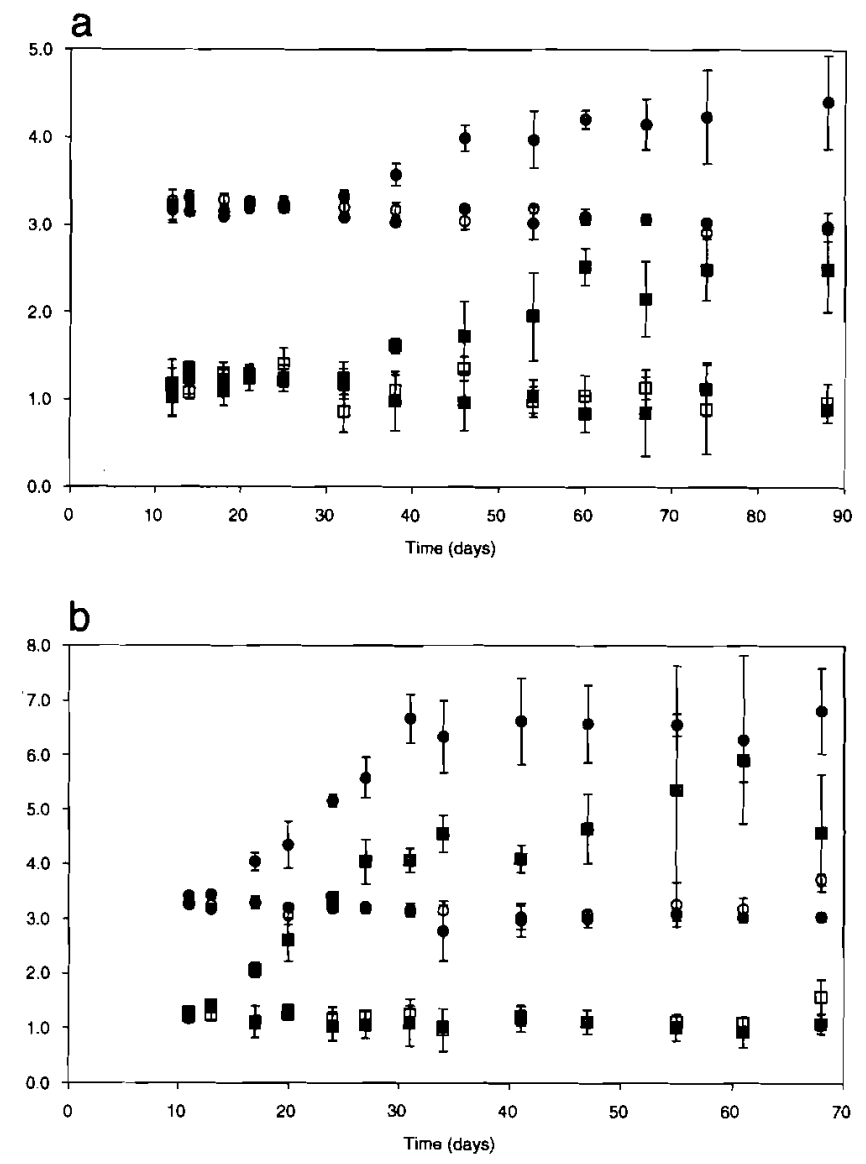

FIGURE 7. Growth at (a) $4^{\circ} \mathrm{C}$ and (b) $8^{\circ} \mathrm{C}$ of either high (circles) or low (squares) levels of $\mathrm{L}$. monocytogenes inoculated into ham treated with either potassium lactate-sodium diacetate (PURASAL P Opti.Form PD 4; open symbols) or potassium lactate (PURASAL HiPure P; closed symbols) compared with untreated control samples (shaded symbols). Standard deviation $(\mathrm{n}=3)$ is also plotted.

conditions $\left(4^{\circ} \mathrm{C}\right)$ and inappropriate storage conditions $\left(8^{\circ} \mathrm{C}\right)$ for MAP ham. Although growth was clearly possible in the untreated ham product, the addition of the potassium lactate-sodium diacetate treatment almost completely eliminated the growth of L. monocytogenes at 4 or $8^{\circ} \mathrm{C}$ (Figs. $3 \mathrm{a}$ and $3 \mathrm{~b}$ and $4 \mathrm{a}$ and $4 \mathrm{~b}$ ), while hams treated with potassium lactate completely suppressed the growth of $L$. monocytogenes at $4^{\circ} \mathrm{C}$ for 90 days (Fig. 5a and $5 \mathrm{~b}$ ) and for 60 days at $8^{\circ} \mathrm{C}$ (Fig. $6 \mathrm{a}$ and $6 \mathrm{~b}$ ). Consistent with other reports $(3,4,14,18,21,22,26,29,32-34)$, neither treatment was listericidal at the levels used but was listeriostatic. Samelis et al. (29), however, found that $6 \%$ lactate was listericidal in some processed meat products.

An additional level of protection against the growth of L. monocytogenes in MAP or vacuum-packed products may be afforded by the presence and growth of lactic acid bacteria. Lactic acid bacteria have an ecological advantage in such products and usually become numerically dominant during storage (36) but without necessarily causing spoilage of the product. Homofermentative lactic acid bacteria, in particular, can reach high concentrations in vacuum-packed or MAP products but without causing overt spoilage (12). The presence of high concentions of other bacteria cre- ates an additional hurdle to the growth of organisms present in lower numbers. This phenomenon has been termed the Jameson Effect $(10,11,13,35)$. Expressed simply, the Jameson Effect describes the often-observed phenomenon that when one microbial species in an environment reaches stationary phase, all other species present also enter stationary phase, irrespective of whether they are at levels normally associated with their maximum population density. The phenomenon is not yet fully explained but can account for the observations summarized in Figure $7 a$ and $7 b$ in which the maximum population density achieved by introduced $L$. monocytogenes appears to be dependent on their initial density in the challenge trial. We interpret this as occurring because the concentration of other bacteria initially present on the ham was the same, irrespective of the level of introduced L. monocytogenes, and because those bacteria reached stationary phase at the same time during the respective challenge trial conditions (i.e., 4 or $8^{\circ} \mathrm{C}$ ). The growth of $L$. monocytogenes was suppressed after the same amount of time. Consequently, the final levels reached by $L$. monocytogenes in the product are dependent on the levels initially introduced. Figure $2 b$ and $2 c$ illustrates the effect most clearly by showing that the cessation of the growth of $L$. monocytogenes corresponds closely with the onset of stationary phase of the aerobic microflora, which is dominated by the lactic acid bacteria. This effect was also noted by Stekelenburg (33). Glass et al. (14) also commented on the contribution of lactic acid bacteria to suppression of pathogen growth in long shelf life processed meats and stated that "manufacturers must optimise the critical balance between increasing shelf life and permitting the growth of spoilage lactic acid bacteria that compete with $L$. monocytogenes for nutrients."

Although full characterization of the likely reduction in risk of listeriosis due to use of listeriostatic agents such as organic acid salts would require extensive modeling, general trends can be inferred from the results in this study. Given the low number of $L$. monocytogenes typically present on processed meats at the point of manufacture, the delay in growth induced by the presence of organic acid salts (and $\mathrm{CO}_{2}$ ), in combination with the growth-suppressing effects of high concentrations of lactic acid bacteria or other indigenous bacteria, would be expected to reduce the risk of listeriosis from vacuum-packed or MAP processed meats. This is expected because, once any $L$. monocytogenes present was able to grow, other bacteria might have reached concentrations high enough to suppress L. monocytogenes growth, i.e., by the Jameson Effect. The magnitude of this suppression might also depend on the relative concentrations of lactic acid bacteria and $L$. monocytogenes initially present. For this reason, it is important to undertake studies with realistic initial levels of $L$. monocytogenes (e.g., $\leq 10 \mathrm{CFU} \mathrm{g} \mathrm{g}^{-1}$ ), as noted by Porto et al. (26) and the present study.

The beneficial effect of the addition of organic acid salts in reducing risk from $L$. monocytogenes could be lessened, however, if the growth suppression applied equally to indigenous bacteria and product shelf lives were extended as a result. Inhibition of the growth of lactic acid bacteria 
and APC was seen in this study (Figs. 3 through 6) and potentially enables an extension of product shelf life. Samelis et al. (29) noted less $\mathrm{pH}$ reduction during prolonged storage of untreated controls than with organic acid salt treated pork frankfurters. Similar results were observed in this study for ham stored at $8^{\circ} \mathrm{C}$ (Table 1). This is possibly because of the inhibition of lactic acid bacteria growth and delay of spoilage processes. Stekelenburg (33) reported inhibition of the growth of lactic acid bacteria and resultant extension of shelf life of 75 to $125 \%$, and in an earlier study, Stekelenburg and Kant-Muermans (34) reported that the growth of $L$. monocytogenes was more inhibited than the growth of a lactic acid bacterium, Lactobacillus curvatus. Extension of shelf life to exploit the inhibition of growth of other microorganisms could lessen the antilisterial benefits of organic acid salt treatments, because the growth of $L$. monocytogenes, while delayed by the treatment, might eventually be possible because of the extended shelf life of the product. Shelf lives of 75 to 90 days for some processed meats, including frankfurters, are expected in United States (29). Shelf lives in Europe are, apparently, similar to those in Australia (28). Stekelenburg and KantMuermans (34) indicate that shelf lives of 3 to 4 weeks at $7^{\circ} \mathrm{C}$ are common. We concur with Glass et al. (14) that manufacturers and retailers need to remain mindful of their reasons for using organic acid additives to processed meats and that the interplay between $L$. monocytogenes risk minimization and product shelf life extension is clearly understood. Optimization of $L$. monocytogenes risk reduction compared with shelf life extension achieved by application of salts of organic acids may need to be evaluated on a case-by-case basis.

Bedie et al. (3) considered that "injured cells may be overlooked or underestimated, despite their potential to repair damage, and proliferate in foods to potentially become a risk." This factor should be considered in the interpretation of the results presented here for the recovery of $L$. monocytogenes on PALCAM agar. Results presented in Figures 4 through 7, however, suggest that PALCAM is a reliable enumeration medium. During the study, we observed that both $L$. monocytogenes and lactic acid bacteria were recovered on deMan Rogosa Sharpe agar (data not shown). From those same figures, whereas the numbers of L. monocytogenes estimated by their growth on PALCAM were constant, the numbers of colonies recovered on deMan Rogosa Sharpe agar often fell below the level recovered on PALCAM (e.g., Fig. 5b). The reasons for this phenomenon are unknown and were not explored further in this study.

In general, the results of this study are consistent with previously published reports concerning cured meat products and demonstrate that organic acid salts are powerful listeriostatic agents. The addition of organic acid salts to cured meats could reduce the risk of listeriosis from processed meats by preventing the growth of $L$. monocytogenes, usually initially present at low levels only, to levels less likely to cause human illness. The microbial ecology of refrigerated vacuum-packed or MAP processed meats is complex, particularly the interplay between product formulation and growth potential of lactic acid bacteria and spoilage bacteria and pathogenic contaminants. This suggests that the potential for shelf life extension achievable with additions of organic acid salts must be considered together with the potential for L. monocytogenes contamination and growth in the product. Further studies to characterize these interactions are being undertaken.

\section{ACKNOWLEDGMENTS}

This study was funded by Purac Asia Pacific Pte. Ltd. and Fibrisol Service Australia Pty. Ltd., and we sincerely thank Mr. Michael Wainwright for his coordination of the project. PURASAL Opti.Form PD 4 and PURASAL HiPure P were kindly supplied by Purac Asia Pacific Pte. Ltd. Hams were provided, and processed, by Don Smallgoods Co. Pty. Ltd. We also thank Ms. Fiona Birrell and Mrs. Lauri Parkinson for their expert technical assistance in undertaking the laborious microbiological testing and Ms. Jill Anderson, Silliker Microtech Laboratories, Melbourne, for provision of the $L$. monocytogenes cultures.

\section{REFERENCES}

1. Angelidis, A. S., and K. Koutsoumanis. 2006. Prevalence and concentration of Listeria monocytogenes in sliced ready-to-eat meat products in the Hellenic retail market. J. Food Prot. 69:938-942.

2. Barmpalia, I. M., I. Geornaras, K. E. Belk, J. A. Scanga, P. A. Kendall, G. C. Smith, and J. N. Sofos. 2004. Control of Listeria monocytogenes on frankfurters with antimicrobials in the formulation and by dipping in organic acid solutions. J. Food Prot. 67:2456-2464.

3. Bedie, G. K., J. Samelis, J. N. Sofos, K. E. Belk, J. A. Scanga, and G. C. Smith. 2001. Antimicrobials in the formulation to control Listeria monocytogenes postprocessing contamination on frankfurters stored at $4^{\circ} \mathrm{C}$ in vacuum packages. J. Food Prot. 64:1949-1955.

4. Blom, H., E. Nerbrink, R. Dainty, T. Hagtvedt, E. Borch, H. Nissen, and T. Nesbakken. 1997. Addition of $2.5 \%$ lactate and $0.25 \%$ acetate controls growth of Listeria monocytogenes in vacuum-packed, sensory-acceptable servelat sausage and cooked ham stored at $4^{\circ} \mathrm{C}$. Int. J. Food Microbiol. 38:71-76.

5. Busani, L., A. Cigliano, E. Taioli, V. Caligiuri, L. Chiavacci, C. Di Bella, A. Battisti, A. Duranti, M. Gianfranceschi, M. C. Nardella, A. Ricci, S. Rolesu, M. Tamba, R. Marabelli, and A. Caprioli. 2005. Prevalence of Salmonella enterica and Listeria monocytogenes contamination in foods of animal origin in Italy. J. Food Prot. 68:17291733.

6. Centers for Disease Control. 1989. Epidemiologic notes and reports listeriosis associated with consumption of turkey franks. Morb. Mortal. Wkly. Rep. 38:267-268.

7. Centers for Disease Control and Prevention. 1999. Update: multistate outbreak of Listeriosis--United States, 1998-1999. Morb. Mort. Week. Rep. 49:1117-1118.

8. Centers for Disease Control and Prevention. 2002. Public health dispatch: outbreak of listeriosis-northeastern United States, 2002. Morb. Mortal. Wkly. Rep. 51:950-951.

9. Choi, S. H., and K. B. Chin. 2003. Evaluation of sodium lactate as a replacement for conventional chemical preservatives in comminuted sausages inoculated with Listeria monocytogenes. Meat Sci. 65:531-537.

10. Coleman, M. E., S. Sandberg, and S. A. Anderson. 2003. Impact of microbial ecology of meat and poultry products on predictions from exposure assessment scenarios for refrigerated storage. Risk. Anal. 23:215-228.

11. Delignette-Muller, M. L., M. Cornu, R. Pouillot, and J. B. Denis. 2006. Use of Bayesian modelling in risk assessment: application to growth of Listeria monocytogenes and food flora in cold-smoked salmon. Int. J. Food Microbiol. 106:195-208.

12. Egan, A. 1983. Lactic acid bacteria of meat and meat products. Antonie Leeuwenhoek 49:327-336.

13. Giménez, B., and P. Dalgaard. 2004. Modelling and predicting the simultaneous growth of Listeria monocytogenes and spoilage microorganisms in cold-smoked salmon. J. Appl. Microbiol. 96:96-109.

14. Glass, K. A., D. A. Granberg, A. L. Smith, A. M. McNamara, M. 
Hardin, J. Mattias, K. Ladwig, and E. A. Johnson. 2002. Inhibition of Listeria monocytogenes by sodium diacetate and sodium lactate on wieners and cooked bratwurst. J. Food Prot. 65:116-123.

15. Gombas, D. E., Y. H. Chen, R. S. Clavero, and V. N. Scott. 2003. Survey of Listeria monocytogenes in ready-to-eat foods. J. Food Prot. 66:559-569.

16. Gravani, R. 1999. Incidence and control of Listeria in food-processing facilities, p. 657-709. In E. Ryser and E. Marth (ed.), Listeria, listeriosis and food safety. Marcel Dekker, Inc., New York.

17. Islam, M., J. R. Chen, M. P. Doyle, and M. Chinnan. 2002. Control of Listeria monocytogenes on turkey frankfurters by generally-recognized-as-safe preservatives. J. Food Prot. 65:1411-1416.

18. Juncher, D., C. S. Vestergaard, J. Soltoft-Jensen, C. J. Weber, G. Bertelsen, and L. H. Skibsted. 2000. Effects of chemical hurdles on microbiological and oxidative stability of a cooked cured emulsion type meat product. Meat Sci. 55:483-491.

19. Legan, J. D., D. L. Seman, A. L. Milkowski, J. A. Hirschey, and M. H. Vandeven. 2004. Modeling the growth boundary of Listeria monocytogenes in ready-to-eat cooked meat products as a function of the product salt, moisture, potassium lactate, and sodium diacetate concentrations. J. Food Prot. 67:2195-2204.

20. Levine, P., B. Rose, S. Green, G. Ransom, and W. Hill. 2001. Pathogen testing of ready-to-eat meat and poultry products collected at federally inspected establishments in the United States, 1990 to 1999. J. Food Prot. 64:1188-1193.

21. Mbandi, E., and L. A. Shelef. 2001. Enhanced inhibition of Listeria monocytogenes and Salmonella Enteritidis in meat by combinations of sodium lactate and diacetate. J. Food Prot. 64:640-644.

22. Mbandi, E., and L. A. Shelef. 2002. Enhanced antimicrobial effects of combination of lactate and diacetate on Listeria monocytogenes and Salmonella spp. in beef bologna. Int. J. Food Microbiol. 76: 191-198.

23. Mead, P. S., E. F. Dunne, L. Graves, M. Wiedmann, M. Patrick, S. Hunter, E. Salehi, F Mostashari, A. Craig, P. Mshar, T. Bannerman, B. D. Sauders, P. Hayes, W. Dewitt, P. Sparling, P. Griffin, D. Morse, L. Slutsker, and B. Swaminathan. 2006. Nationwide outbreak of listeriosis due to contaminated meat. Epidemiol. Infect. 134:744-751.

24. Mol, J. H. H., J. E. A. Hietbrink, H. W. M. Mollen, and J. van Tintern. 1971. Observations on microflora of vacuum packed sliced cooked meat products. J. Appl. Bacteriol. 34:377-397.

25. OzFoodNet. 2006. Quarterly report, 1 October to 31 December 2005. Comm. Dis. Intell. 30:1-188.

26. Porto, A. C. S., B. Franco, E. S. Sant'Anna, J. E. Call, A. Piva, and J. B. Luchansky. 2002. Viability of a five-strain mixture of Listeria monocytogenes in vacuum-sealed packages of frankfurters, commercially prepared with and without 2.0 or $3.0 \%$ added potassium lactate, during extended storage at 4 and $10^{\circ} \mathrm{C}$. J. Food Prot. 65:308315.

27. Qvist, S., K. Sehested, and P. Zeuthen. 1994. Growth suppression of Listeria monocytogenes in a meat product. Int. J. Food Microbiol. 24:283-293.
28. Ross, T., S. Rasmussen, J. Sumner, G. Paoli, and A. Fazil. 2005. Listeria monocytogenes in Australian processed meat products: risks and their management. Meat and Livestock Australia, Sydney.

29. Samelis, J., G. K. Bedie, J. N. Sofos, K. E. Belk, J. A. Scanga, and G. C. Smith. 2002. Control of Listeria monocytogenes with combined antimicrobials after postprocess contamination and extended storage of frankfurters at $4^{\circ} \mathrm{C}$ in vacuum packages. J. Food Prot. 65 : 299-307.

30. Samelis, J., A. Kakouri, K. G. Georgiadou, and J. Metaxopoulos. 1998. Evaluation of the extent and type of bacterial contamination at different stages of processing of cooked ham. J. Appl. Microbiol. 84:649-660.

31. Samelis, J., J. N. Sofos, M. L. Kain, J. A. Scanga, K. E. Belk, and G. C. Smith. 2001. Organic acids and their salts as dipping solutions to control Listeria monocytogenes inoculated following processing of sliced pork bologna stored at $4^{\circ} \mathrm{C}$ in vacuum packages. $J$. Food Prot. 64:1722-1729.

32. Seman, D. L., A. C. Borger, J. D. Meyer, P. A. Hall, and A. L. Milkowski. 2002. Modeling the growth of Listeria monocytogenes in cured ready-to-eat processed meat products by manipulation of sodium chloride, sodium diacetate, potassium lactate, and product moisture content. J. Food Prot. 65:651-658.

33. Stekelenburg, F. K. 2003. Enhanced inhibition of Listeria monocytogenes in frankfurter sausage by the addition of potassium lactate and sodium diacetate mixtures. Food Microbiol. 20:133-137.

34. Stekelenburg, F. K., and M. L. T. Kant-Muermans. 2001. Effects of sodium lactate and other additives in a cooked ham product on sensory quality and development of a strain of Lactobacillus curvatus and Listeria monocytogenes. Int. J. Food Microbiol. 66:197-203.

35. Stephens, P. J., J. A. Joynson, K. W. Davies, R. Holbrook, H. M. Lappin-Scott, and T. J. Humphrey. 1997. The use of an automated growth analyser to measure recovery times of single heat-injured Salmonella cells. J. Appl. Microbiol. 83:445-455.

36. Stiles, M. E. 1996. Biopreservation by lactic acid bacteria. Antonie Leeuwenhoek 70:331-345.

37. Sutherland, P. S., and R. J. Porritt. 1997. Listeria monocytogenes, p. 333-378. In A. D. Hocking, G. Amold, I. Jenson, K. Newton, and P. Sutherland (ed.), Foodborne microorganisms of public health significance. Australian Institute of Food Science and Technology Inc., North Sydney.

38. Tompkin, R. B. 2002. Control of Listeria monocytogenes in the foodprocessing environment. J. Food Prot. 65:709-725.

39. Uyttendaele, M., P. De Troy, and J. Debevere. 1999. Incidence of Listeria monocytogenes in different types of meat products on the Belgian retail market. Int. J. Food Microbiol. 53:75-80.

40. Weaver, R. A., and L. A. Shelef. 1993. Antilisterial activity of sodium, potassium or calcium lactate in pork liver sausage. J. Food Saf. 13:133-146.

41. Wong, T. L., G. V. Carey-Smith, L. Hollis, and J. A. Hudson. 2005. Microbiological survey of prepackaged pate and ham in New Zealand. Lett. Appl. Microbiol. 41:106-111. 